\title{
Performance evaluation of Cryo Laser Phoresis technique as biophysical method to promote diclofenac sodium cutaneous perfusion
}

\author{
Marcio Adriano Andréo ${ }^{1}$, Iasmin Mimoto Rufino ${ }^{1}$, Daniela Cecilia Ortiz de Orue Ubaldo ${ }^{1}$, Estela \\ Boaro Herbst ${ }^{1}$, Heron Dominguez Torres da Silva ${ }^{1}$, Pedro Gonçalves de Oliveira ${ }^{2}$, Marcio Ferrari ${ }^{3}$, \\ Paulo Cesar Pires Rosa ${ }^{4, *}$, Patrícia Santos Lopes ${ }^{1}$, Vânia Rodrigues Leite-Silva ${ }^{1}$
}

\begin{abstract}
${ }^{1}$ Institute of Environment, Chemistry and Pharmaceutical Sciences, Federal University of São Paulo Diadema, SP, Brazil, ${ }^{2}$ Faculty of Pharmacy, Anhembi Morumbi, University, São Paulo, SP, Brazil, ${ }^{3}$ Department of Pharmacy, Federal University of Rio Grande do Norte, Natal, RN, Brazil, ${ }^{4}$ Faculty of Pharmaceutical Sciences State University of Campinas, Campinas, SP, Brazil
\end{abstract}

\begin{abstract}
Aiming to alter and/or improve permeation of active compounds in the skin, many strategies have been developed, including biophysical methods. One of the physical absorption techniques, currently known as Cryo Laser Phoresis (CLP), consists of an apparatus that emits radiation on polar or nonpolar molecules of the active substance, resulting in faster penetration when in comparison to the standard topical application. The goal of this work was to evaluate the efficacy of a method that proposes to increase cutaneous permeation of diclofenac sodium by using CLP technique. The influence on permeation was evaluated ex vivo, using Franz cell and human skin obtained from cosmetic surgery. The results were evaluated using statistical methods and data exploratory analysis: clusters, k-means and Principal Component Analysis. The results showed a larger increase in the concentration of diclofenac sodium in the dermis with the use of laser. In all samples (with or without laser application) it was observed that skin surface showed an amount of diclofenac sodium and that there was no active passage to the receptor liquid, suggesting that diclofenac sodium was not absorbed. These results indicate that CLP, when used under the conditions described in this study, is able to increase diclofenac sodium penetration and its retention into deeper layers.
\end{abstract}

Uniterms: Cryo Laser Phoresis/dematologic use. Cutaneous permeation. Diclofenac sodium/cutaneous permeation. Franz cell.

\begin{abstract}
No sentido de alterar e/ou melhorar a penetração de substâncias na pele, diversas estratégias têm sido desenvolvidas, variando desde a aplicação de novos veículos e ativos encapsulados, até equipamentos que atuam por métodos biofísicos. Uma das técnicas de absorção física, atualmente conhecida como Crio Laser Forese (CLF), consiste em um aparato que emite radiação sobre moléculas polares ou apolares da substância ativa, tornando sua penetração mais rápida, se comparada à administração tópica comum. $\mathrm{O}$ objetivo deste trabalho foi avaliar a eficácia de um método que propõe aumentar a permeação cutânea do diclofenaco de sódio incorporado a um gel, por meio do uso da CLF. A influência sobre a permeação foi avaliada ex vivo, utilizando célula de Franz e pele humana obtida de cirurgia plástica. Os resultados foram balizados mediante aplicação de métodos estatísticos e análise exploratória de dados: clusters, k-means e Análise por Componentes Principais. Os resultados demonstraram aumento na concentração do diclofenaco de sódio na derme com o uso do laser. Em todas as amostras (com ou sem aplicação de laser), observou-se, uma quantidade de diclofenaco de sódio na superfície da pele e que não houve passagem de ativo para o líquido do receptor, sugerindo que o diclofenaco de sódio não foi absorvido. Estes resultados indicam que CLF usada sob as condições descritas neste estudo é capaz de aumentar a penetração do diclofenaco de sódio e sua retenção em camadas mais profundas da pele
\end{abstract}

Unitermos: Crio Laser Forese/uso em dermatologia. Permeação cutânea. Diclofenaco de sódio/permeação cutânea. Célula de Franz.

\footnotetext{
*Correspondence: P. C. P. Rosa. Faculty of Pharmaceutical Sciences. State University of Campinas. Rua Alexandre Fleming, s/n - Distrito Barão Geraldo - 13083-887 - Campinas-SP, Brazil. E-mail: paulo.rosa@ffc.unicamp.br
} 


\section{INTRODUCTION}

The skin has many functions and amongst them it is possible to emphasize its role as a barrier against exogenous agents, its utility to keep the homeostasis of the organism and to prevent internal water loss. Beyond that, it has been shown that it is an appropriate route for treatment systems, through transdermal administration of drugs (Leite-Silva et al., 2012). Several methods have been developed to increase the penetration of substances through skin. This includes the use of substances that act as permeation enhancers (chemical enhancers) in formulations or the development of new methods that modify the lipid and protein organization, inter and intracellular of the stratum corneum (biophysical enhancers) and can reversibly decrease the skin's barrier property (Lopes et al., 2008; Silva et al., 2010).

Throughout the years there was a significant growth of knowledge in biochemical and metabolic processes involving substance flow through skin (Fluhr, Feingold, Elias, 2006). There are many factors that influence substance permeation through skin, such as formulation, particle size, component concentration, skin thickness, $\mathrm{pH}$ and sebum production, among others (Gallagher et al., 2003; Benson, 2005; Trommer, Neubert, 2006; Baroli, 2010; Leite-Silva et al., 2012).

Several methods have been formulated to promote augmentation of transdermic transportation, having obtained varying levels of success. The promoting agents of chemical absorption can improve the skin's permeability to small molecules, but also can lead to irritation of the surface of the skin or other factors that may limit their use. Iontophoresis uses electric fields to permeate ionized molecules through the skin using electrophoresis and electroosmosis for non-ionized molecules. This technique can be useful for applications that contain peptides and small proteins. Physical methods that temporarily improve skin permeability such as electroporation and ultrasound are used, representing perspectives in the application of drugs of low or high molecular weight (Patil, Saraogi, 2014). However, not much studying has been done about the use of CryoLaser as a method of biophysical permeation.

In spite of the use of chemical permeation enhancers being widely studied, remarkable attention has been given to the benefits of biophysical permeation promoting techniques. One of them is known as Cryo Laser Phoresis (CLP), also named Cryopass Therapy, developed by C.I.R.C.E srl - Italy (Bonizzoni, 2007). It is applied with a device called Lasericemed, which emits a laser radiation on polar or nonpolar active substances and claims to make their absorption faster and more efficient when compared to the standard topical administration. The laser emission releases photons that collide with electrons of active substance molecules. This impact leads to photon energy transfer to electrons from more external orbitals, as kinetic energy form. This increases gravitational acceleration, allowing molecules to pass through skin and be delivered to the desired site (Terraneo et al., 2011).

The aim of this work was to evaluate the Cryo Laser Phoresis efficiency as biophysical method to promote diclofenac sodium cutaneous permeation.

\section{MATERIAL AND METHODS}

\section{Material}

Hydroxyethylcellulose (CAS 9004-62-0, Mapric Produtos Farmacosmeticos). The diclofenac sodium working standard (monosodium acid 2-[(2,6-dichlorophenyl) amino] benzene acetic salt) was donated by Medley Pharmaceutical Industry and methylchloroisothiazolinone and methylisothiazolinone were donated by Pro-ServQuimica LTDA. Acetonitrile (J. T. Baxter ${ }^{\mathrm{TM}}$ ) and methanol (J. T. Baxter ${ }^{\mathrm{TM}}$ ) were from HPLC gradeand phosphate buffer (PBS) components ( $\mathrm{NaCl}$ - MW: 58,44; $\mathrm{KCl}$ - MW: 74,55; $\mathrm{Na}_{2} \mathrm{HPO}_{4}$ - MW: 141,96 and $\mathrm{KH}_{2} \mathrm{PO}_{4}-\mathrm{MW}: 136,09$ ) were P. A. grade from Synth $^{\circledR}$. The tape stripping tapes (Standard S-Squame Disc $\mathrm{CuDe} 15109$ ) were from CuDerm. The syringe filtersMilex were from Milipore ${ }^{\circledR}$. The $\mathrm{C} 18$ chromatography column within $25 \mathrm{~cm}$ x $4.6 \mathrm{~mm}$ dimensions, $5 \mu \mathrm{m}$ particle size was from $\mathrm{ACE} \mathrm{E}^{\mathrm{TM}}$.

\section{Formulation}

A gel was formulated using low irritant power and low cost raw materials (Table I). The gel was frozen until $-20^{\circ} \mathrm{C}$ in suitable a package to attach to the device.

\section{Permeation test}

UNIFESP's Ethics Committee previously approved the use of skin obtained by excision in cosmetic surgery, with protocol number 631972 . After preparation, the skin was stored at a temperature of approximately $-20^{\circ} \mathrm{C}$.

The experiment was performed using dual compartment vertical diffusion cells (Franz cells) that were specifically modified and adapted exclusively for this experiment, with the superior portion suitable to receive a package that will be connected to the laser (Figure 1A). The skin was rehydrated for one hour with 
TABLE I - Composition of formulations $(\%, \mathrm{w} / \mathrm{w})$ evaluated

\begin{tabular}{lccc}
\hline Ingredient & F1 & F2 & F3 \\
\hline Hydroxyethylcellulose & 0.6 & 0.6 & 0.6 \\
Methylchloroisothiazolinone (and) Methylisothiazolinone & 0.1 & 0.1 & 0.1 \\
Diclofenac Sodium & 1.0 & 1.5 & 2.0 \\
Water & 98.3 & 97.8 & 97.3 \\
\hline
\end{tabular}

phosphate buffer (PBS) pH 7.4. PBS was added to the receptor compartment and the system was immersed in a bath at $37^{\circ} \mathrm{C}$, and stirred continuously for half an hour to stabilize the system.

The bottle containing the active frozen gel was attached to the device and placed in contact with the skin for $10 \mathrm{~min}$, with or without laser contact, in this case, employing the device Lasericemed turned on (Figure 1B). It is just an illustration, without the human skin and the receptor liquid only to demonstrate how the laser is used. This study was performed in triplicate.
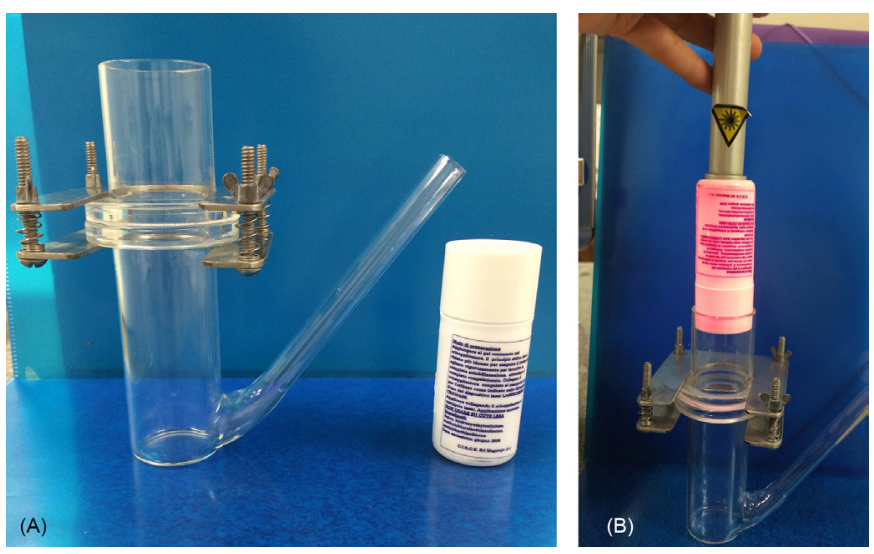

FIGURE 1 - (A) Adapted Franz cell and the package where the gel was frozen; (B) Simulation of the laser attached to the package that contains diclofenac sodium frozen gel.

The receptor liquid was collected at intervals of 10 and $20 \mathrm{~min}$. After $20 \mathrm{~min}$, the gel applied to skin surface was removed with swabs ${ }^{\mathrm{TM}}$. Next, stratum corneum (SC) extraction was performed by "tape stripping" technique and the detachment of epidermis from dermis was performed (water at $60{ }^{\circ} \mathrm{C}$ for $90 \mathrm{~s}$ ). The samples were stored after being soaked in methanol for approximately 15 min.

Afterwards, an aliquot from the supernatant liquid from each sample was removed and submitted to HPLC analysis. The final samples were: $10 \mathrm{~min}$ receptor liquid, 20 min receptor liquid, swab, tapes $1-5$, tapes $6-10$, epidermis and dermis, with and without laser application.

\section{Determination of diclofenac sodium in the samples}

The methodology of diclofenac sodium analysis was developed based on conditions described on USP 35 (2013) monograph and also on the methodology described by Klimes et al. (2001).

Considering these aspects, the chromatographic quantification of diclofenac sodium was performed by using HPLC degree solvents (acetonitrile and methanol) and C18 chromatography column within $25 \mathrm{~cm}$ x $4.6 \mathrm{~mm}$ dimensions, $5 \mu \mathrm{m}$ particle size. Diclofenac sodium (working standard), with $99 \%$ purity was used as secondary standard. The analyses were performed in a liquid chromatograph model ACELLA 600, from Thermo Scientific ${ }^{\mathrm{TM}}$, equipped with quaternary pump system, column oven, automatic injector and diode array detector (DAD). Data was processed by ChromQuest ${ }^{\mathrm{TM}}$ software.

In addition, the following chromatography system parameters were also evaluated: retention factor, asymmetry $(10 \%)$ and number of theoretical plates, according to (USP 35, 2013) recommended parameters.

In connection with the sample preparation, with $0.5 \mathrm{~mL}$ fixed volume, all samples were previously filtered through $0.45 \mu \mathrm{m}$ syringe filters and stored in $1.5 \mathrm{~mL}$ vials. The samples were diluted, when necessary, so active expected concentrations were coherent with the ones determined at calibration curve. Chromatography conditions for diclofenac sodium analysis were based on the US Pharmacopoeia (USP 35), with some modifications for optimizing the method, according to gel matrix and biological matrix content, assessing parameters as: stationary phase and chromatographic column dimensions, content, mobile phase flow, temperature, injection volume, sample solution and standard solution concentration related to HPLC equipment response.

After optimization, an isocratic method was established with mobile phase composed of $30 \%$ phosphate buffer (pH 2.5) and 70\% acetonitrile, with $1.0 \mathrm{~mL} \cdot \mathrm{min}^{-1}$ flow, using C18 column with $25 \mathrm{~cm} \times 4.6 \mathrm{~mm}, 5 \mu \mathrm{m}$ particle size and DAD detector monitoring $254 \mathrm{~nm}$ 
wavelength. The injected volume of each sample was $25 \mu \mathrm{L}$ and 9 min run time.

A stock solution was prepared in a volumetric flask, transferring $12.5 \mathrm{mg}$ of diclofenac sodium in $25 \mathrm{~mL}$ of methanol, obtaining a $500 \mu \mathrm{g} \cdot \mathrm{mL}^{-1}$ solution. From the stock solution and using $10 \mathrm{~mL}$ volumetric flasks, dilutions were prepared leading to the concentrations: $2.5 ; 5.0 ; 12.5$; $25 ; 50 ; 100$ and $150 \mu \mathrm{g} . \mathrm{mL}^{-1}$ in methanol. The standard concentrations for the calibration curve were prepared in triplicate and analyzed in the previously described chromatography conditions.

\section{Statistical analysis}

At the data exploratory phase, $t$ Student test was applied, which allowed verifying significant differences between "With Laser" and "Without Laser" situations, to the Dermis (D). Given the hypothesis absence, a priori, to all other results, cluster analysis method application was chosen ( $p$-value $<0.05$ was considered to be statistically significant).

\section{RESULTS AND DISCUSSION}

Diclofenac sodium was chosen as a marker due to its hydrophilic characteristics that hinder its flow through the skin's lipid layer (Lopes et al., 2008) and because it can be a good alternative for challenging the biophysical enhancer. Gaur et al. (2014) had studied the transdermal formulations containing permeation enhancers that cause skin damage and diclofenac was used as a model drug. The presence of ceramid specifically promotes drug permeation through SC and dermis and also contributes to stability and non-irritancy.

Escribano et al. (2003) evaluated the transdermal permeation of sodium diclofenac. Permeation studies were carried out in vitro using human skin from plastic surgery as a membrane - as we did in our research. However, they used chemical enhancers instead of biophysical methods to improved diclofenac permeation.

The influence of an erbium:YAG laser on the transdermal delivery of drugs across skin was studied in vitro by Lee et al. (2001). The researchers concluded that the use of an erbium:YAG laser is a good method for enhancing transdermal absorption of both lipophilic and hydrophilic drugs, because it allows precise control of SC removal, and this ablation of SC can be reversible to its original normal status. Nevertheless, the laser used in this work does not have ablation potential.

The Figure 2 shows the comparative performance of samples submitted to the laser treatment and not submitted to the laser treatment; highlighted are the Swab and dermis samples, in gray are the other samples with inexpressive graphic representation.

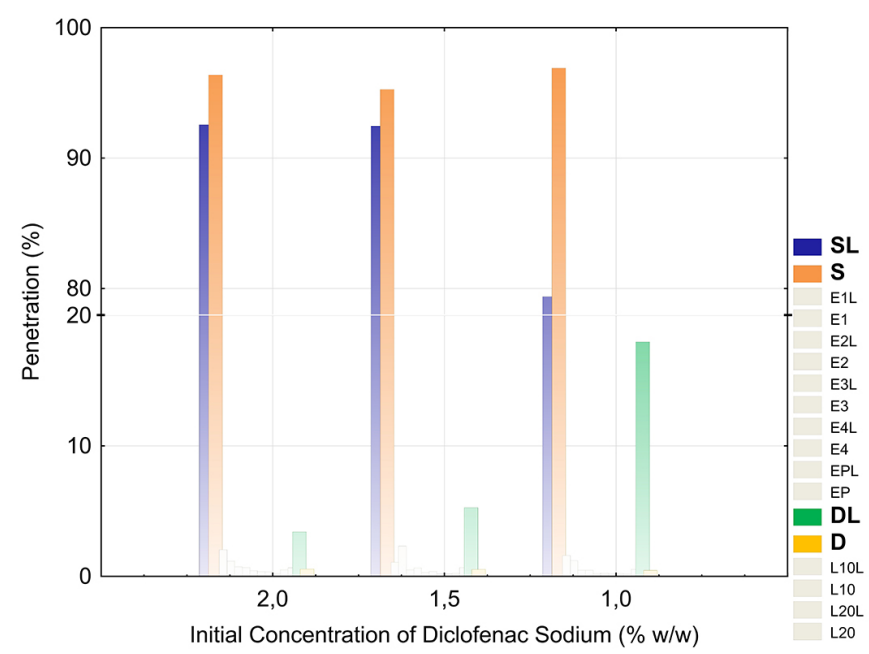

FIGURE 2 - Comparative performance of samples submitted to the laser treatment and not submitted to laser treatment. Notes: $\mathrm{SL}=\mathrm{Swab}$ with laser; $\mathrm{S}=\mathrm{Swab}$ without laser; $\mathrm{E} 1 \mathrm{~L}=$ tape strip 1 to 5 with laser; E1 = tape strip 1 to 5 without laser; E2L = tape strip 6 to 10 with laser; E2 = tape strip 6 to 10 without laser; E3L $=$ tape strip 11 to 15 with laser; E3 = tape strip 11 to 15 without laser; $\mathrm{E} 4 \mathrm{~L}=$ tape strip 16 to 20 with laser; E4 = tape strip 16 to 20 without laser; $\mathrm{EPL}=$ epidermis with laser; $\mathrm{EP}=$ epidermis without laser; $\mathrm{DL}=$ Dermis with laser; $\mathrm{D}=$ Dermis without laser; $\mathrm{L} 10 \mathrm{~L}=$ receptor liquid $10 \mathrm{~min}$ with laser; $\mathrm{L} 10=$ receptor liquid $10 \mathrm{~min}$ without laser, $\mathrm{L} 20 \mathrm{~L}=$ receptor liquid $20 \mathrm{~min}$ with laser; $\mathrm{L} 20=$ receptor liquid $20 \mathrm{~min}$ without laser.

The statistical analysis reinforces the validity of these data. The Figure 3 shows a hierarchical grouping analysis dendrogram (K-means) that allowed verifying the evident dissimilarity of results obtained from the swab (with and without laser and dermis (with laser)), when compared to the other experimental data.

Complementarily to cluster analysis, data was treated by Principal Component Analyses (PCA) method application, permitting the gathering of similar behavior data groups (Figure 4). It basically consists of the diagonalization of a symmetric data matrix, resulting in a new group of variables (principal components), which are linear combinations of the original variables and noncorrelated. In this way, a new space is generated in which the variables can be projected and classified into categories or groups. The application of this method allowed the clear differentiation (grouping) between the variables to be verified, highlighting the swab and the dermis (Figure 4A), confirming that the laser treatment promotes results on dermis that show singular behavior when compared 


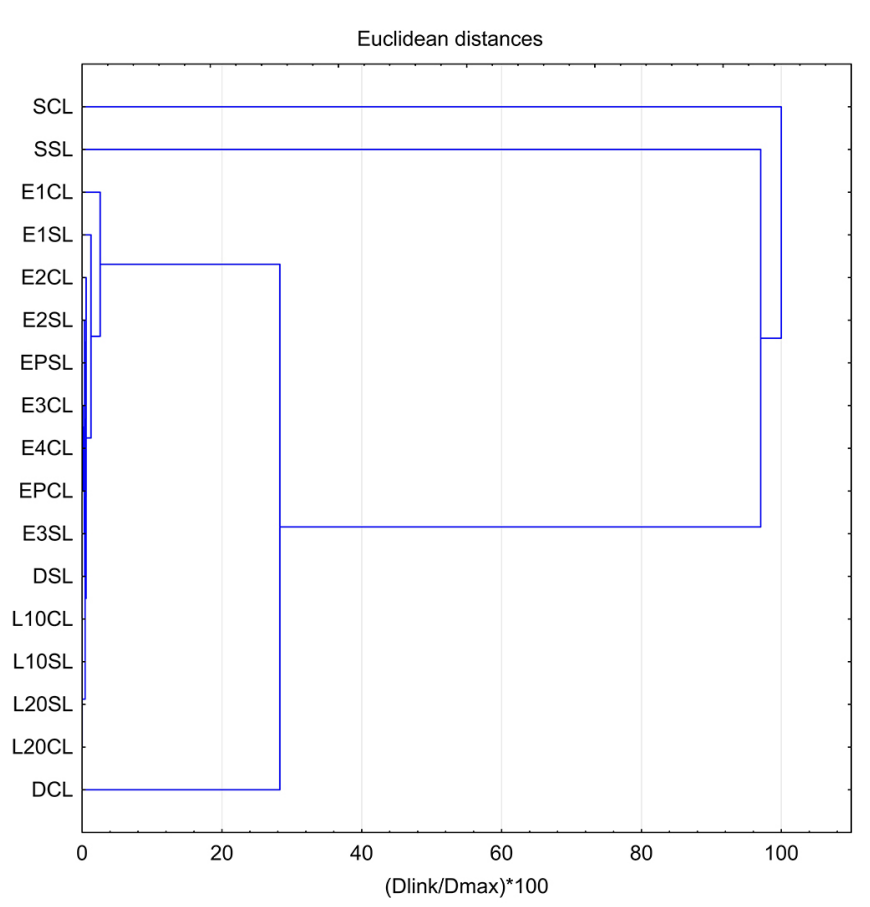

FIGURE 3 - Cluster Analysis about differentiation of dermis with laser and Swab with and without laser when compared to the other experimental data. Notes: $\mathrm{SCL}=$ Swab with laser; SSL= Swab without laser; E1CL = tape strip 1 to 5 with laser; E1SL $=$ tape strip 1 to 5 without laser; E2CL = tape strip 6 to 10 with laser; E2SL = tape strip 6 to 10 without laser; E3CL = tape strip 11 to 15 with laser; E3SL = tape strip 11 to 15 without laser; $\mathrm{E} 4 \mathrm{CL}=$ tape strip 16 to 20 with laser; E4SL = tape strip 16 to 20 without laser; $\mathrm{EPCL}=$ epidermis with laser; $\mathrm{EPSL}=$ epidermis without laser; $\mathrm{DCL}=$ Dermis with laser; $\mathrm{DSL}=$ Dermis without laser; $\mathrm{L} 10 \mathrm{CL}=$ receptor liquid $10 \mathrm{~min}$ with laser; $\mathrm{L} 10 \mathrm{SL}=$ receptor liquid $10 \mathrm{~min}$ without laser, $\mathrm{L} 20 \mathrm{CL}=$ receptor liquid 20 min with laser; L20SL= receptor liquid 20 min without laser. to the other result groups. Figure 4B highlights the differentiation of dermis with laser (DCL) and Swab with and without laser (SCL and SSL), compared to the results set considering all tested concentrations.

According Yilmaz and Ciltas (2015), diverse methodologies are described in the literature to diclofenac qualitative and quantitative analysis, using many analytical techniques. However, most of them use high performance liquid chromatography with ultraviolet detection (HPLCUV) (Arcelloni et al., 2001; Bhattacharya et al., 2013). Therefore, this work methodology was developed based on conditions of analysis described on USP 35 (2013) monograph and on the methodology described by Klimes et al. (2001).

The method presented suitable specificity as it considered the excipients used in the gel vehicle. Representative chromatograms from samples with or without diclofenac sodium are shown on Figure 5.

The analytical curve, based on the expected active concentrations on the different skin layers, presented results and Coefficient of Variation (CV) suitable with the aim of the analysis. These analyses were performed in triplicate and their results are shown in Table II.

The obtained coefficient of determination was 0.9966 , which shows good explaining ability and linearity coefficient of variation of $4.7 \%$ from Detection Limit (DL), determined in $3.3 \mu \mathrm{g} . \mathrm{mL}^{-1}$ until maximum concentration established in calibration $\left(50 \mu \mathrm{g} \cdot \mathrm{mL}^{-1}\right)$.

The chromatographic system evaluation parameter values to analyze the standards were: retention factor $=$ 4.2 , asymmetry $(10 \%)=1.16$, number of theoretical plates $=15582$, indicating chromatographic system adequacy
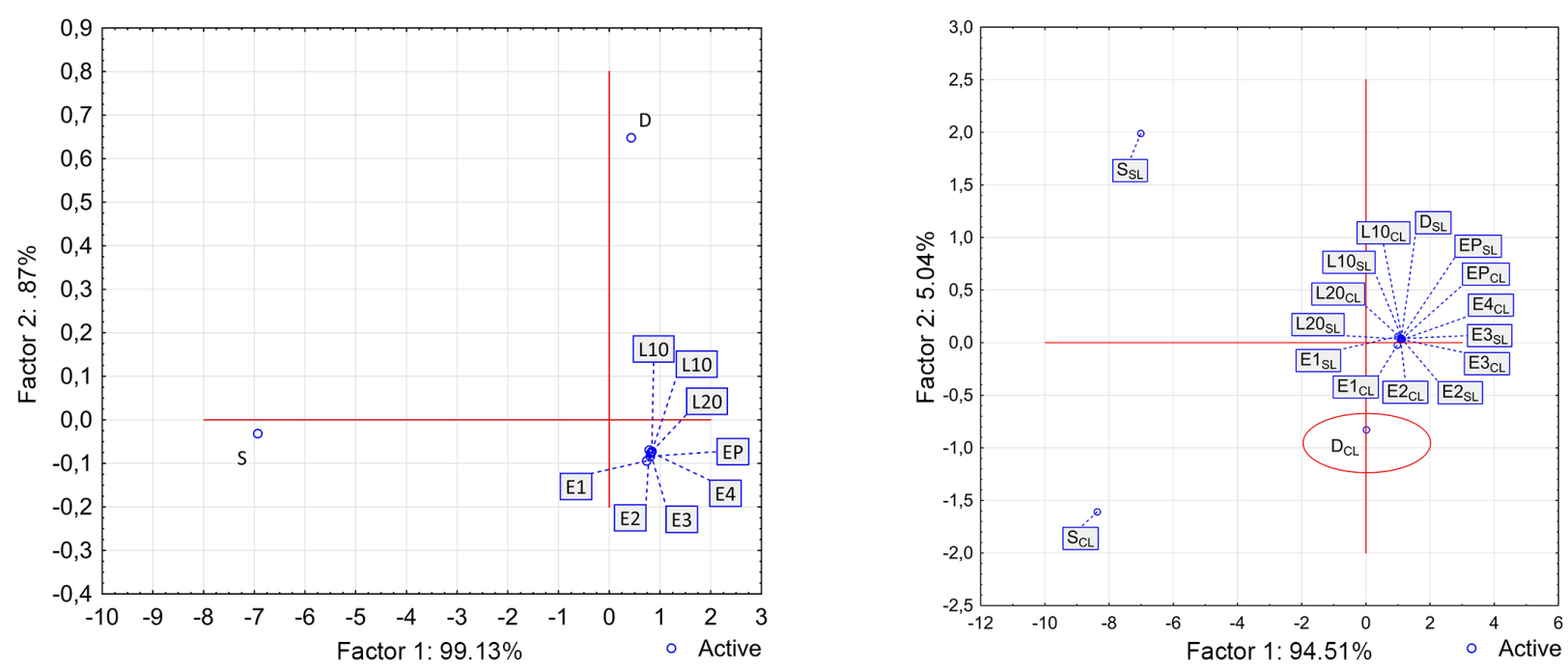

FIGURE 4 - Principal Component Analysis method application, allowing the gathering of similar behavior data groups. (A) Differentiation of variables swab and dermis when submitted to laser treatment, (B) differentiation of dermis with laser (DCL) and swab with and without laser (SCL and SSL) compared to the results set considering all tested concentrations. 

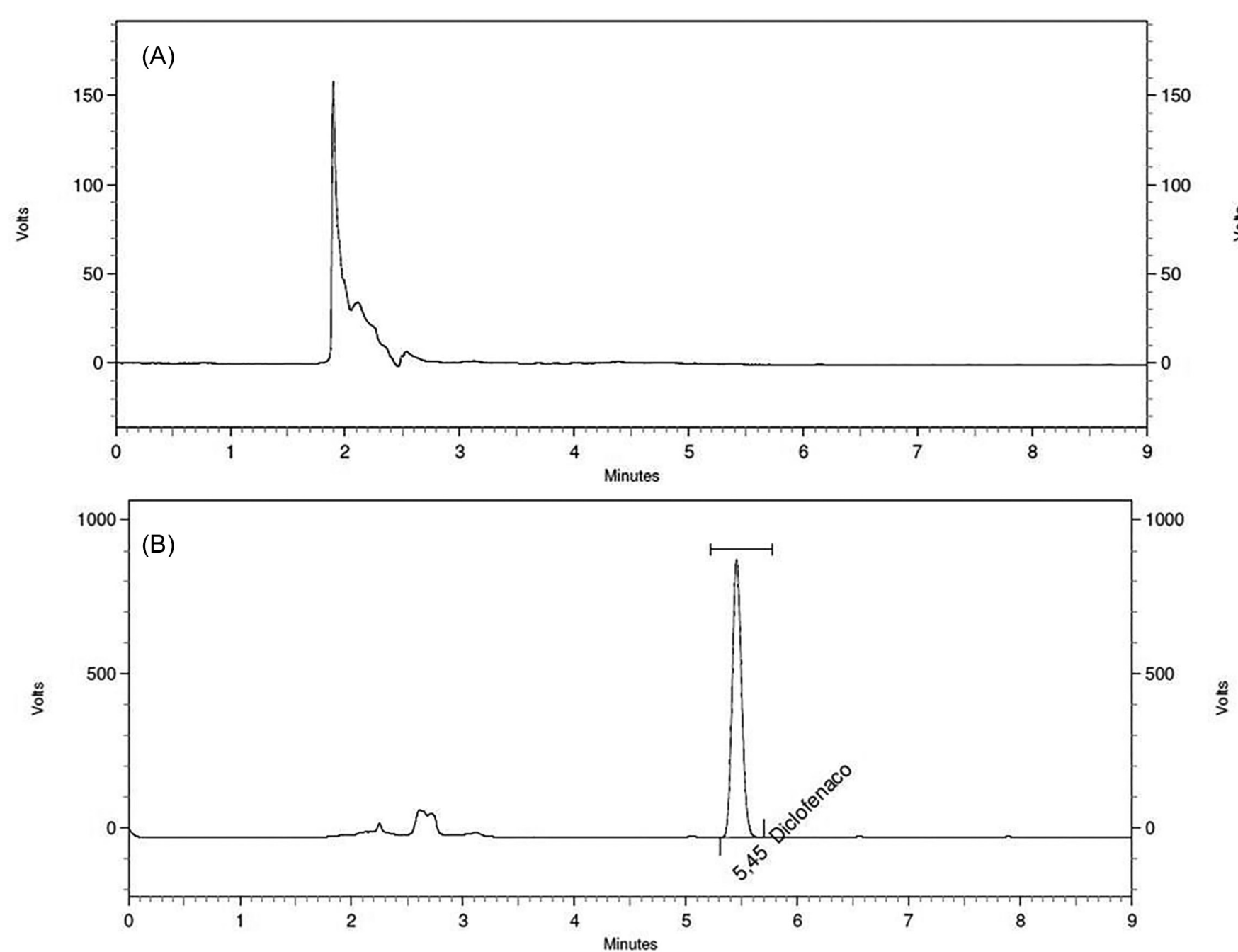

FIGURE 5 - Chromatogram analysis obtained from samples without diclofenac sodium addition (A) and samples with diclofenac sodium (B). Chromatographic conditions: chromatographic column ACE® C18 ( $25 \mathrm{~cm} \mathrm{x} 4.6 \mathrm{~mm}, 5 \mu \mathrm{m}$ particle size), mobile phase containing $30 \%$ phosphate buffer ( $\mathrm{pH}$ 2,5) and $70 \%$ acetonitrile, $1.0 \mathrm{~mL} \cdot \mathrm{min}^{-1}$ flow, $254 \mathrm{~nm}$ detection, $25 \mu \mathrm{L}$ injected volume and analysis time $9 \mathrm{~min}$.

TABLE II - Results obtained from diclofenac sodium solution analysis to build an analytical curve

\begin{tabular}{lccccc}
\hline Concentration (mg.mL-1 $)$ & Area 1 & Area 2 & Area 3 & Mean \pm SD & CV (\%) \\
\hline 0.0025 & 564670 & 564970 & 558828 & $562823 \pm 3463$ & 0.6 \\
0.005 & 734929 & 742080 & 737941 & $738317 \pm 2831$ & 0.4 \\
0.0125 & 2042415 & 2043344 & 2053681 & $2046480 \pm 5106$ & 0.25 \\
0.025 & 3781948 & 3794774 & 3786593 & $3787772 \pm 5302$ & 0.14 \\
0.05 & 7237005 & 7245341 & 7855082 & $7445809 \pm 289419$ & 0.4 \\
\hline
\end{tabular}

Notes: $\mathrm{CV}=$ Coefficient of Variation. $\mathrm{SD}=$ Standard Deviations

and compatibility with the USP 35 (2013) recommended parameters. The values of all evaluation parameters to the standards are on Table III.

These results of performance parameters, including specificity, range, linearity, precision (CV), LOD (limit of detection) and LOQ (limit of quantification), presented by the HPLC method used for the determination of diclofenac sodium in the samples obtained from the permeation tests, assure the sensibility and confidence necessary for the assessment of the data connected with the potential of the 
TABLE III - Evaluation parameters values to all standard solution analysis

\begin{tabular}{lccc}
\hline $\begin{array}{l}\text { Concentration } \\
(\boldsymbol{\mu g} / \mathbf{m L})\end{array}$ & $\begin{array}{c}\text { Retention } \\
\text { Factor }\end{array}$ & $\begin{array}{c}\text { Assymetry } \\
\mathbf{( 1 0 \% )}\end{array}$ & $\begin{array}{c}\text { Number of } \\
\text { Theoretical } \\
\text { Plates }\end{array}$ \\
\hline \multirow{3}{*}{2.5} & 4.23 & 1.15 & 15842 \\
& 4.23 & 1.17 & 16097 \\
\hline \multirow{3}{*}{5.0} & 4.23 & 1.16 & 16192 \\
\hline & 4.22 & 1.17 & 16000 \\
& 4.22 & 1.18 & 15713 \\
12.5 & 4.21 & 1.16 & 15961 \\
\hline \multirow{3}{*}{25} & 4.22 & 1.15 & 15945 \\
& 4.21 & 1.15 & 16022 \\
& 4.22 & 1.15 & 15980 \\
\hline \multirow{3}{*}{50} & 4.21 & 1.16 & 15742 \\
& 4.21 & 1.15 & 15712 \\
& 4.22 & 1.16 & 15745 \\
\hline
\end{tabular}

CLP to increase the cutaneous permeation of diclofenac sodium.

The performed analysis, in all three investigated concentrations $(1.0 \%, 1.5 \%, 2.0 \%)$ presented the same behavior, as shown on Figure 2. All showed a higher increase of the substance in the dermis with the laser use, suggesting that laser employment in these conditions increases diclofenac sodium penetration and its retention into deeper layers. In all samples (with or without laser application), it is observed that skin surface (swab) showed, as expected, a much higher diclofenac sodium quantity (out of method work range) and that there is no active passage to the receptor liquid, suggesting that diclofenac sodium is not absorbed.

Using an intermediate concentration as a numeric example, it is possible to verify that without laser employment, the analysis representing the first 5 layers from stratum corneum $\left(0.049 \mathrm{mg} \cdot \mathrm{mL}^{-1}\right)$, layers 6 to 10 (0.014 mg. $\left.\mathrm{mL}^{-1}\right)$, layers 11 to $15\left(0.008 \mathrm{mg} \cdot \mathrm{mL}^{-1}\right)$ and layers 16 to $20\left(0.004 \mathrm{mg} \cdot \mathrm{mL}^{-1}\right)$ show that the found diclofenac sodium quantity decreases according to the analyzed stratum corneum depth, remaining low in dermis $\left(0.011 \mathrm{mg} \cdot \mathrm{mL}^{-1}\right)$. As in the samples that underwent laser treatment, the samples that represent the first 5 stratum corneum layers $\left(0.024 \mathrm{mg} . \mathrm{mL}^{-1}\right)$, layers 6 to 10 (0.011 mg. $\left.\mathrm{mL}^{-1}\right)$, layers 11 to $15\left(0.006 \mathrm{mg} \cdot \mathrm{mL}^{-1}\right)$ and layers 16 to $20\left(0.004 \mathrm{mg} \cdot \mathrm{mL}^{-1}\right)$ also presented as a result a decrease in concentrations according to the analyzed stratum corneum depth and a significant increase in the dermis $\left(0.117\right.$ mg.mL $\left.\mathrm{m}^{-1}\right)$.

New studies must be conducted with distinct physicochemical properties molecules, aiming to measure the permeation enhancer capacity on different situations. Finally it must be highlighted that, because of operational limitations, this experiment was adapted to evaluate only the effects of laser application on a frozen active solution in a hydrophilic gel, when applied over the skin. According to Bonizzoni (2007), after applying the gel with the laser, skin surface should be exposed to a light beam again by a scanning device, which could have contributed to the permeation process if it had been used in this experiment.

\section{CONCLUSION}

The results indicate that the Cryo Laser Phoresis technique, when used under the conditions described in this study, is able to enhance skin permeation of diclofenac sodium and potentially of other molecules with similar physical-chemical proprieties, thus constituting an interesting alternative to drug administration, especially in situations in which penetration in deeper skin layer is necessary and where the systemic use may be unfeasible or may be capable to promote unpleasant reactions.

\section{REFERENCES}

ARCELLONI, C.; LANZI, R.; PEDERCINI, S.; MOLTENI, G.; FERMO, I.; PONTIROLIC, A.; PARONI, R. Highperformance liquid chromatographic determination of diclofenac in human plasma after solid-phase extraction. J. Chromatogr. B: Biomed. Sci. Appl., v.763, n.1/2, p.195200, 2001.

BAROLI, B. Penetration of nanoparticles and nanomaterials in the skin: fiction or reality? J. Pharm. Sci., v.99, n.1/2, p.21-50, 2010.

BENSON, H.A. Transdermal drug delivery: penetration enhancement techniques. Curr. Drug Deliv., v.2, n.1, p.2333,2005 .

BHATTACHARYA, S.S.; BANERJEE, S.; GHOSH, A.K.; CHATTOPADHYAY, P.; VERMA, A.; GHOSH, A. A RP-HPLC method for quantification of diclofenac sodium released from biological macromolecules. Int. J. Biol. Macromol., v.58, p.354-359, 2013. 
BONIZZONI, E. Medical apparatus for cutaneous administration of medicaments. European Patent Application EP 1752190A1, 14 fev. 2007.

ESCRIBANO, E.; CALPENA, A.C.; QUERALT, J.; OBACH, R.; DOMÉNECH, J. Assessment of diclofenac permeation with different formulations: anti-inflammatory study of a selected formula. Eur. J. Pharm. Sci., v.19, n.4, p.203-210, 2003.

FLUHR, J.W.; FEINGOLD, K.R.; ELIAS, P.M. Transepidermal water loss reflects permeability barrier status: validation in human and rodent in vivo and ex vivo models. Exp. Dermatol., v.15, n.7, p.483-492, 2006.

GALLAGHER, S.J.; TROTTET, L.; CARTER, T.P. HEARD, C.M. Effects of membrane type and liquid/liquid phase boundary on in vitro release of ketoprofen from gel formulations. J. Drug Target., v.11, n.6, p.373-379, 2003.

GAUR, P.K.; PUROHIT, S.; KUMAR, Y.; MISHRA, S.; BHANDARI, A. Preparation, characterization and permeation studies of a nanovesicular system containing diclofenac for transdermal delivery. Pharm. Dev. Technol., v.19, n.1, p.48-54, 2014.

KLIMES, J.; SOCHOR, J.; DOLEZAL, P.; KÖRNER, J. HPLC evaluation of diclofenac in transdermal therapeutic preparations. Int. J. Pharm., v.217, n.1/2, p.153-160, 2001.

LEE, W.-R.; SHEN, S.-C.; LAI, H.-H.; FANG, J.-Y. Transdermal drug delivery enhanced and controlled by erbium: YAG laser: a comparative study of lipophilic and hydrophilic drugs. J. Control. Release, v.75, n.1/2, p.155-156, 2011.

LEITE-SILVA, V.R.; ALMEIDA, M.M.; FRADIN, A.; GRICE, J.E.; ROBERTS, M.S. Delivery of drugs applied topically to the skin. Expert Rev. Dermatol., v.7, n.4, p.383-397, 2012.
LOPES, P.S.; PINTO, C.A.S.O.; BABY, A.R.; VELASCO, M.V.R.; TAQUEDA, M.E.; KANEKO, T.M. Evaluation of in vitro percutaneous enhancement effect of papain and pequi oil on diclofenac sodium permeation through human skin. Rev. Bras. Ciênc. Farm., v.44, n.2, p.225-231, 2008.

PATIL, U.K.; SARAOGI, R. Natural products as potential drug permeation enhancer in transdermal drug delivery system. Arch. Dermatol. Res., v.306, n.5, p.419-426, 2014.

SILVA, J.A.; APOLINÁRIO, A.C.; SOUZA, M.S.R.; DAMASCENO, B.P.G.L.; MEDEIROS, A.C.D. Administração cutânea de fármacos: desafios e estratégias para o desenvolvimento de formulações transdérmicas. Rev. Ciênc. Farm. Básica Apl., v.31, n.3, p.125-131, 2010.

TERRANEO, L.; FINATI, E.; VIRGILI, E.; DEMARTINI, G.; DE ANGELIS, L.; DALL'AGLIO, R.; FRASCHINI, F.; SAMAJA, M.; PARONI, R. LNCaP prostate cancer growth in vivo: oncostatic effects of melatonin as compared to hypoxia and reoxygenation. In: SPIESS, P.E., ed. Prostate cancer: original scientific reports and case studies. Rijeka: In Tech Europe, 2011. cap.5, p.77-90.

TROMMER, H.; NEUBERT, R.H. Overcoming the stratum corneum: the modulation of skin penetration: a review. Skin Pharmacol. Physiol., v.19, n.2, p.106-121, 2006.

UNITED States Pharmacopeia: USP 35; National Formulary: NF 30. Rockville: United States Pharmacopeial Convention, 2013.

YILMAZ, B.; CILTAS, U. Determination of diclofenac in pharmaceutical preparations by voltammetry and gas chromatography methods. J. Pharm. Anal., v.5, n.3, p.153160, 2015.

Received for publication on $23^{\text {rd }}$ June 2015 Accepted for publication on $28^{\text {th }}$ November 2015 